\title{
Petanque: Apa saja faktor fisik penentu prestasinya?
}

\author{
Yulingga Nanda Hanief *, Ardhi Mardiyanto Indra Purnomo \\ Jurusan Pendidikan Jasmani Kesehatan dan Rekreasi, Universitas Nusantara PGRI Kediri. \\ Jalan KH. Ahmad Dahlan No.76, Mojoroto, Kota Kediri, Jawa Timur 64112, Indonesia. \\ * Corresponding Author. Email: yulingganandahanief@gmail.com \\ Received: 12 August 2019; Revised: 9 December 2019; Accepted: 10 December 2019
}

\begin{abstract}
Abstrak
Petanque merupakan permainan dengan melempar bola besi (BOSI) sedekat mungkin pada sasaran berupa bola kayu (cochonnet). Permainan ini menuntut akurasi yang tinggi. Tujuan penelitian ini adalah untuk mengetahui faktor fisik dominan penentu prestasi petanque. Penelitian ini merupakan deskriptif kuantitatif. Populasi sekaligus sampel pada penelitian ini adalah semua atlet petanque Kota Kediri yang berjumlah 15 atlet dengan usia rata-rata 15 tahun. Teknik pengambilan data berupa tes dan pengukuran dengan item tes yaitu tinggi badan, panjang lengan, panjang telapak tangan, kekuatan otot lengan, kelentukan pergelangan tangan, keseimbangan, power otot lengan, kekuatan peras tangan, dan koordinasi mata-tangan. Teknik analisis data menggunakan analisis konfirmatori dengan bantuan SPSS versi 23. Hasil penelitian menunjukkan bahwa dari sembilan variabel yang dianalisis terdapat enam indikator variabel yang menunjukkan sebagai faktor fisik dominan penentu prestasi petanque, antara lain tinggi badan, panjang lengan, kekuatan otot lengan, kelentukan pergelangan tangan, keseimbangan, dan koordinasi mata-tangan. Untuk mendapatkan hasil lemparan yang akurat, faktor fisik tersebut harus menjadi penekanan utama setiap pelatih ketika berurusan dengan atlet pemula.
\end{abstract}

Kata Kunci: kondisi fisik; anthropometri; biomotor; petanque.

\section{Petanque: What are the physical factors that determine performance?}

\begin{abstract}
Petanque is a game by throwing an iron ball (BOSI) as close as possible to the target in the form of a wooden ball (cochonnet). This game demands high accuracy. The purpose of this study was to determine the dominant physical factors determining petanque achievement. This research is a quantitative descriptive. The population as well as the sample in this study were all petanque athletes in the City of Kediri totaling 15 athletes with an average age of 15 years. Data collection techniques in the form of tests and measurements with test items namely height, arm length, palm length, arm muscle strength, wrist flexion, balance, arm muscle power, squeeze strength, and eye-hand coordination. The data analysis technique used explanatory analysis with the help of SPSS version 23. The results showed that of the nine variables analyzed there were six indicator variables that showed as dominant physical factors determining petanque achievement, including height, arm length, arm muscle strength, wrist flexion, balance and eye-hand coordination. To get accurate toss results, these physical factors must be the main emphasis of every coach when dealing with novice athletes.
\end{abstract}

Keywords: physical condition; anthropometry; biomotor; petanque.

How to Cite: Hanief, Y., \& Purnomo, A. (2019). Petanque: Apa saja faktor fisik penentu prestasinya?. Jurnal Keolahragaan, 7(2), 116-125. doi:https://doi.org/10.21831/jk.v7i2.26619

https://doi.org/10.21831/jk.v7i2.26619

\section{PENDAHULUAN}

Petanque adalah permainan yang berasal dari Provence, Prancis, yang telah menjadi hal biasa di bebrapa negara Eropa (Okilanda et al., 2018; Sudiadharma \& Suardi, 2019). Petanque dimainkan menggunakan bola dengan diameter 70-80 $\mathrm{mm}$ dan berat 650-800 g (Laksana, Pramono, \& Mukarromah, 2017; Loser et al., 2011; Suwanto, Kristiyanto, \& Doewes, 2018).
Petanque di beberapa Negara memiliki perbedaan, salah satunya di Negara Turki, petanque dikenal dengan istilah Bocce dan Bowls di Negara Inggris (Laksana et al., 2017; Turkmen, Bozkus, \& Altintas, 2013). Meskipun petanque merupakan olahraga lama, namun perkembangan di Indonesia masih tergolong baru. Momentum SEA Games ke-26 di Jakarta-Palembang sebagai penanda berdirinya Federasi Olahraga Petanque 
Indonesia (FOPI) tanggal 11 bulan Maret tahun 2011 (Suwanto et al., 2018).

Sejak berdirinya FOPI, olahraga petanque mulai disosialisasikan oleh universitas-universitas dengan program studi olahraga di lima Provinsi, yaitu Provinsi Bali, Provinsi Jawa Barat, Provinsi Jawa Timur, Daerah Khusus Ibukota (DKI) Jakarta, dan Provinsi Riau. Kemunculan tim petanque di berbagai daerah ini ditandai dengan menggelar latihan secara terjadwal. Beberapa orang tertarik untuk menjadi pelatih, begitu pun pelatih tertarik untuk merekrut bibit berbakat guna mengukir prestasi pada cabang olahraga yang baru disosialisasikan. Berbagai event kejuaraan dilaksanakan sebagai media untuk mengukur kemampuan sekaligus mengukir prestasi.

Eksistensi olahraga petanque ditandai dengan banyaknya perkumpulan atau klub olahraga petanque diberbagai daerah. Kegiatan pelatihan bagi pelatih petanque dari tingkat pemula sampai tingkat professional dilaksanakan dibeberapa daerah. Hal ini juga disertai pelaksanaan beberapa event kejuaraan baik tingkat daerah, provinsi, maupun nasional.

Petanque termasuk olahraga yang cukup unik, alat dan lapangan yang digunakan sederhana, dan cara bermainnya sangat mudah (Sinaga, 2019; Suwanto et al., 2018). Permainan petanque tidak dibatasi oleh usia, semua orang dapat mengikutinya (Souef, 2015). Permainan ini membutuhkan konsentrasi dan akurasi (Juhanis, B, \& Nur, 2019; Muladana, 2019). Petanque terdiri dari beberapa nomor diantaranya single man and woman, double man and woman, triple man and woman dan shooting (Agustina \& Priambodo, 2017). Pertandingan dengan nomor shooting dilakukan dengan jarak 6, 7, 8 dan 9 meter. Poin yang diperoleh pada nomor shooting ialah 0,3 , dan 5 pada tiap shooting yang berhasil, sehingga permainan ini benar-benar memerlukan konsentrasi dan akurasi agar dapat berprestasi.

Pointing adalah teknik yang bertujuan mendekatkan bola logam atau boule ke bola kayu (jack). Ada tiga macam teknik pointing yaitu rolling point, half lobe point, dan high lobe point. Shooting adalah teknik yang bertujuan membawa bola logam lawan jauh dari bola kayu (bola sasaran). Ada tiga jenis shooting yaitu full iron shot, in front shot dan rolling shot (Isknadar, Ridlo, \& Oktaviana, 2019).

Sama halnya dengan olahraga lain, petanque selain penguasaan teknik, taktik, dan strategi juga memerlukan kondisi fisik yang baik (Isknadar et al., 2019). Permainan petanque tidak mengeluarkan energi yang banyak dibanding olahraga lainnya (Irawan, Permana, Akromawati, $\&$ Yang-Tian, 2019). Namun jika melihat aktivitas selama bertanding, permainan petanque banyak menguras energi. Setiap selesai pertandingan, atlet harus mengambil bola besi yang dilempar dari berbagai jarak, mulai 6, 7, 8 dan 9 meter. Kemudian agar sampai masuk final harus melalui beberapa pertandingan dan faktanya pertandingan petanque dilakukan di ruang terbuka yang memberi peluang sinar matahari untuk menyengat kulit. Benefit dari bermain petanque salah satunya adalah berkontribusi pada kesejahteraan fisik dan mental orang yang mempraktikkannya (Hernández \& de los Fayos, 2009).

Permasalahan yang dihadapi oleh pelatih selama ini adalah belum diketahuinya faktor kondisi fisik dominan penentu prestasi petanque, sehingga para pelatih kesulitan dalam menyusun program latihan sekaligus mencari bakat atlet. Selama ini para pelatih hanya beranggapan bahwa kebutuhan kondisi fisik pada cabang olahraga petanque hampir sama seperti olahraga dengan karakteristik melempar pada sasaran, seperti bola tangan, basket, golf dan lainnya.

Beberapa penelitian telah banyak dilakukan yang mengaitkan antara kondisi fisik dengan petanque, diantaranya penelitian yang dilakukan oleh (Pradana \& Nurkholis, 2019) menyimpulkan bahwa tinggi badan, panjang lengan dan keseimbangan menentukan ketepatan shooting. Menurut (Pradana \& Nurkholis, 2019) tinggi badan mampu berkontribusi sebesar $45,1 \%$ pada ketepatan shooting. Sedangkan panjang lengan mampu berkontribusi sebesar $-5,9 \%$ dengan korelasi negatif. Sedangkan (Widodo \& Hafidz, 2018) menyimpulkan bahwa panjang lengan seorang atlet dan koordinasi antara mata dan tangan memberikan kontribusi pada akurasi shooting. Temuan tersebut saling bertolak belakang kaitannya dengan kontribusi panjang lengan yang menyatakan bahwa semakin panjang lengan akan menghasilkan kecepatan linier (Rizal, 2012) dengan jarak tempuh menurut aturan pertandingan petanque, yaitu 9 meter (jarak terjauh).

Klub petanque Kota Kediri telah menjadi daya tarik untuk diteliti karena meskipun tergolong baru, namun para atletnya telah menorehkan berbagai prestasi baik di tingkat daerah, provinsi maupun nasional. Club petanque Kota Kediri memberi warna tersendiri bagi cabang olahraga petanque di Jawa Timur khususnya, dan di Indonesia pada umumnya, karena club petanque Kota Kediri telah mengukir prestasi ditingkat nasional. Club petanque Kota Kediri terdiri dari 
15 atlet baik putra maupun putri dengan usia ratarata 15 tahun. Mereka berlatih setiap hari dan buah dari hasil latihannya adalah disematkannya juara umum cabang olahraga petanque pada Pekan Olahraga Provinsi (Porprov) Jawa Timur tahun 2019 yang diselenggarakan di Kabupaten Bojonegoro. Dari 15 atlet yang bertanding, mendapatkan 2 medali emas dan 3 medali perak.

Memandang kelebihan dan kekurangan hasil temuan, penulis tertarik untuk mengupas kesenjangan hasil penelitian tersebut. Selama ini belum pernah dilakukan penelitian tentang faktor fisik apa saja sebagai penentu prestasi petanque. Beberapa peneltian hanya menemukan korelasinya saja, tanpa menemukan faktor fisik apa saja yang berpengaruh terhadap pencapaian pretasi pada olahraga petanque. Aspek kondisi fisik yang diteliti pun dibatasi pada aspek antropometri dan biomotor. Aspek antropometri yang ditetapkan adalah tinggi badan, panjang lengan dan panjang telapak tangan. Sementara aspek biomotor meliputi kekuatan otot lengan, kelentukan pergelangan tangan, keseimbangan, power otot lengan, kekuatan peras tangan, dan koordinasi matatangan.

Penelitian ini memiliki urgensi, mengingat olahraga petanque adalah olahraga yang baru berkembang di Indonesia dan juga beberapa penelitian terkait faktor fisik penentu prestasi pada olahraga petanque juga belum ditemukan. Penelitian ini bertujuan untuk mengetahui faktor fisik dominan penentu prestasi olahraga petanque.

\section{METODE}

Penelitian ini merupakan jenis penelitian korelasional dengan pendekatan kuantitatif dan rancangan analisis faktor konfirmatori. Populasi sekaligus sampel dalam studi ini adalah seluruh atlet petanque Kota Kediri yang berjumlah 15 atlet dengan rata-rata usia 15 tahun, sehingga teknik sampling pada penelitian ini menggunakan sampel jenuh (Hanief \& Himawanto, 2017).

Teknik pengumpulan data pada penelitian ini menggunakan tes \& pengukuran. Adapun faktor fisik yang diukur terdiri dari faktor antropometri dan faktor biomotor. Faktor antropometri meliputi tinggi badan, panjang lengan, dan panjang telapak tangan. Faktor biomotor meliputi kekuatan otot lengan, kelentukan pergelangan tangan, keseimbangan, power otot lengan, kekuatan peras tangan, dan koordinasi mata-tangan. Teknik analisis data pada penelitian ini adalah teknik analisis konfirmatori. Uji prasyarat statistik meliputi uji normalitas, dan uji linieritas.
Analisis faktor digunakan untuk menjelaskan hubungan antara sejumlah perubahan yang independen antara satu dengan yang lain untuk mengetahui faktor dominan. Pengujian hipotesis pada penelitian ini yakni dengan menentukan koefisien korelasi masing-masing predictor, persamaan regresi $\mathrm{Y}$ atas setiap variabel predictor, persamaan regresi $\mathrm{Y}$ atas semua variabel predictor secara simultan dengan koefisien korelasi ganda. Perhitungan dalam pengujian hipotesis dengan Kaiser-Meyer-Olkin and Barlett's tesf of spherecity, Anti-image correlation test, Total variance explained test, Communalities, Component matrix, dan Component score coefficient matrix. Data diolah dengan bantuan software SPSS 23.

\section{HASIL DAN PEMBAHASAN}

Tabel 1 menunjukkan deskripsi data pada setiap variabel. Data yang disajikan meliputi nilai minimal, nilai maksimal, nilai rata-rata (mean) dan standar deviasi. Hasil uji normalitas data (Tabel 2) menunjukkan bahwa data tinggi badan, panjang lengan, kelentukan pergelangan tangan, keseimbangan, kekuatan peras tangan dan koordinasi mata-tangan berdistribusi normal. Sedangkan data panjang telapak tangan, kekuatan otot lengan dan power otot lengan berdistribusi tidak normal. Hasil uji linieritas ditunjukkan pada (Tabel 3) yang mana skor deviation from linearity $>0,05$ sehingga antara $\mathrm{X}$ dan $\mathrm{Y}$ memiliki hubungan yang linier.

Analisis faktor dalam penelitian ini digunakan untuk menyusun faktor dari satu set variabel yang dianggap layak untuk dianalisis. Sub-variabel pengukuran sudah ditentukan jauh sebelum analisis dilakukan. Faktor anthropometri dibentuk dari tinggi badan, panjang lengan, dan panjang telapak tangan, sedangkan faktor biomotor dibentuk dari kekuatan otot lengan, kelentukan pergelangan tangan, keseimbangan, power otot lengan, kekuatan peras tangan dan koordinasi mata-tangan. Analisis yang akan digunakan adalah $R$ Factor untuk melihat korelasi antara sub-variabel, setelah didapat nilai dari $R$ factor kemudian dilakukan Data Reduction untuk menghasilkan variabel baru yang mencakup beberapa variabel, dari 9 variabel yang menjadi faktor dominan penentu prestasi petanque tersebut akan diuji apakah semuanya menjadi variabel penting atau hanya sebagian saja yang layak untuk dianalisis dan dikelompokkan menjadi faktor utama. 


\section{Factor Analysis I}

Hasil output KMO and Bartlett's Test (Tabel 4) menunjukkan nilai KMO-MSA sebesar 0,525 dan nilai Sig. $=0.004<0.05$, hal ini menunjukan bahwa kumpulan variabel pada penelitian ini adalah signifikan dan dapat diproses lebih lanjut. Selanjutnya data akan diolah dan diproses dengan melihat besarnya korelasi parsial antara dua variabel dengan tetap mengikut sertakan semua variabel. Pendeteksian ini dilakukan dengan melihat Anti Image Correlation yang menghasilkan nilai Measure of Sampling Adequacy (MSA) antara 0 hingga 1. Bila MSA = 1 variabel tersebut dapat diprediksi tanpa kesalahan oleh variabel lain, bila MSA > 0.5 variabel masih bisa diprediksi dan bisa dianalisis lebih lanjutdan bila MSA < 0,5 maka variabel harus dieliminasi dan tidak bisa dianalisis lebih lanjut atau dikeluarkan dari set variabel lainnya.

Berdasarkan hasil Anti-image Matrices Correlation yang ditunjukkan pada (Tabel 5) ternyata terdapat beberapa variabel yang memiliki MSA dibawah 0,50 yaitu panjang telapak tangan $(0,334)$, power otot lengan $(0,285)$, dan kekuatan peras tangan $(0,411)$. Tiga variabel tersebut harus direduksi ulang dan harus dikeluarkan atau dieliminasi karena tidak signifikan untuk uji lanjutan.

Langkah selanjutnya adalah mereduksi ulang variabel dengan factor analysis II dengan tidak menyertakan variabel panjang telapak tangan, power otot lengan, dan kekuatan peras tangan karena pada langkah analisis yang pertama keduanya memiliki nilai MSA di bawah 0,5 yang berarti faktor tersebut tidak memenuhi syarat untuk disertakan dalam factor analysis II.

Tabel 1. Deskripsi Data

\begin{tabular}{lccccc}
\hline & N & Minimum & Maximum & Mean & Std. Deviation \\
\hline Tinggi Badan & 15 & 155.00 & 175.50 & 164.4533 & 5.64015 \\
Panjang Lengan & 15 & 68.00 & 78.00 & 72.4600 & 3.00257 \\
Panjang Telapak Tangan & 15 & 18 & 79 & 23.13 & 15.338 \\
Kekuatan Otot Lengan & 15 & 11 & 27 & 18.47 & 4.518 \\
Kelentukan Pergelangan Tangan & 15 & 70 & 87 & 76.33 & 5.740 \\
Keseimbangan & 15 & 41 & 60 & 48.27 & 5.365 \\
Power Otot Lengan & 15 & 180 & 384 & 263.00 & 60.111 \\
Kekuatan Peras Tangan & 15 & 16 & 41 & 30.67 & 7.047 \\
Koordinasi Mata Tangan & 15 & 4 & 19 & 11.40 & 4.579 \\
Prestasi Petanque & 15 & 13 & 57 & 27.40 & 13.362 \\
Valid N (listwise) & 15 & & & & \\
\hline
\end{tabular}

Tabel 2. Hasil Uji Normalitas

\begin{tabular}{|c|c|c|c|c|}
\hline Variabel & $\mathrm{N}$ & Signifikansi & Probabilitas & Kesimpulan \\
\hline Tinggi Badan & & 0,200 & 0,05 & Normal \\
\hline Panjang Lengan & & 0,200 & 0,05 & Normal \\
\hline Panjang Telapak Tangan & & 0,000 & 0,05 & Tidak Normal \\
\hline Kekuatan Otot Lengan & & 0,027 & 0,05 & Tidak Normal \\
\hline Kelentukan Pergelangan Tangan & & 0,142 & 0,05 & Normal \\
\hline Keseimbangan & 15 & 0,170 & 0,05 & Normal \\
\hline Power Otot Lengan & & 0,011 & 0,05 & Tidak Normal \\
\hline Kekuatan Peras Tangan & & 0,200 & 0,05 & Normal \\
\hline Koordinasi Mata Tangan & & 0,200 & 0,05 & Normal \\
\hline Prestasi Petanque & & 0,079 & 0,05 & Normal \\
\hline
\end{tabular}

Tabel 3. Hasil Uji Linieritas

\begin{tabular}{cccc}
\hline Variabel & Deviation from Linearity & Signifikansi & Kesimpulan \\
\hline $\mathrm{X}_{1} \mathrm{Y}$ & 0,170 & 0,05 & Berpola Linier \\
$\mathrm{X}_{2} \mathrm{Y}$ & 0,518 & 0,05 & Berpola Linier \\
$\mathrm{X}_{3} \mathrm{Y}$ & 0,313 & 0,05 & Berpola Linier \\
$\mathrm{X}_{4} \mathrm{Y}$ & 0,603 & 0,05 & Berpola Linier \\
$\mathrm{X}_{5} \mathrm{Y}$ & 0,812 & 0,05 & Berpola Linier \\
$\mathrm{X}_{6} \mathrm{Y}$ & 0,891 & 0,05 & Berpola Linier \\
$\mathrm{X}_{7} \mathrm{Y}$ & 0,262 & 0,05 & Berpola Linier \\
$\mathrm{X}_{8} \mathrm{Y}$ & 0,396 & 0,05 & Berpola Linier \\
$\mathrm{X}_{9} \mathrm{Y}$ & 0,663 & 0,05 & Berpola Linier \\
\hline
\end{tabular}


Jurnal Keolahragaan 7 (2), 2019 -120

Yulingga Nanda Hanief, Ardhi Mardiyanto Indra Purnomo

Tabel 4. Hasil KMO and Bartlett's Test Analisis Faktor Fisik Dominan Penentu prestasi Petanque

\begin{tabular}{lrr}
\hline Kaiser-Meyer-Olkin Measure of Sampling Adequacy. & .525 \\
Bartlett's Test of Sphericity & Approx. Chi-Square & 62.408 \\
& df & 36 \\
& Sig. & .004 \\
\hline
\end{tabular}

Tabel 5. Hasil Anti-image Matrices Correlation Analisis Faktor Fisik Dominan Penetu Prestasi Petanque

\begin{tabular}{|c|c|c|c|c|c|c|c|c|c|}
\hline $\begin{array}{l}\text { Anti-image } \\
\text { Correlatio }\end{array}$ & $\begin{array}{l}\text { Tinggi } \\
\text { Badan }\end{array}$ & $\begin{array}{l}\text { Panjang } \\
\text { Lengan }\end{array}$ & $\begin{array}{l}\text { Panjang } \\
\text { Telapak } \\
\text { Tangan }\end{array}$ & $\begin{array}{c}\text { Kekuatan } \\
\text { Otot } \\
\text { Lengan }\end{array}$ & $\begin{array}{c}\text { Kelentukan } \\
\text { Pergelangan } \\
\text { Tangan }\end{array}$ & Keseimbangan & $\begin{array}{l}\text { Power } \\
\text { Otot } \\
\text { Lengan }\end{array}$ & $\begin{array}{c}\text { Kekuatan } \\
\text { Peras } \\
\text { Tangan }\end{array}$ & $\begin{array}{c}\text { Koordinasi } \\
\text { Mata } \\
\text { Tangan }\end{array}$ \\
\hline Tinggi Badan & $.549^{a}$ & -.730 & -.205 & .407 & -.147 & .179 & .347 & -.479 & -.172 \\
\hline $\begin{array}{l}\text { Panjang } \\
\text { Lengan }\end{array}$ & -.730 & $.653^{\mathrm{a}}$ & .355 & .077 & .310 & .047 & -.175 & .068 & -.043 \\
\hline $\begin{array}{l}\text { Panjang } \\
\text { Telapak } \\
\text { Tangan }\end{array}$ & -.205 & .355 & $.334^{\mathrm{a}}$ & .405 & .140 & .048 & .422 & -.373 & .486 \\
\hline $\begin{array}{l}\text { Kekuatan Otot } \\
\text { Lengan }\end{array}$ & .407 & .077 & .405 & $.578^{\mathrm{a}}$ & .147 & -.013 & .304 & -.582 & .080 \\
\hline $\begin{array}{l}\text { Kelentukan } \\
\text { Pergelangan } \\
\text { Tangan }\end{array}$ & -.147 & .310 & .140 & .147 & $.664^{\mathrm{a}}$ & -.479 & -.115 & .043 & -.050 \\
\hline Keseimbangan & .179 & .047 & .048 & -.013 & -.479 & $.616^{\mathrm{a}}$ & .450 & -.496 & -.169 \\
\hline $\begin{array}{l}\text { Power Otot } \\
\text { Lengan }\end{array}$ & .347 & -.175 & .422 & .304 & -.115 & .450 & $.285^{\mathrm{a}}$ & -.746 & .282 \\
\hline $\begin{array}{l}\text { Kekuatan } \\
\text { Peras Tangan }\end{array}$ & -.479 & .068 & -.373 & -.582 & .043 & -.496 & -.746 & $.411^{\mathrm{a}}$ & -.232 \\
\hline $\begin{array}{l}\text { Koordinasi } \\
\text { Mata Tangan }\end{array}$ & -.172 & -.043 & .486 & .080 & -.050 & -.169 & .282 & -.232 & $.672^{\mathrm{a}}$ \\
\hline
\end{tabular}

Tabel 6. Hasil KMO and Bartlett's Test Analisis Faktor Fisik Dominan Penentu prestasi Petanque

\begin{tabular}{lrr}
\hline Kaiser-Meyer-Olkin Measure of Sampling Adequacy. & .646 \\
Bartlett's Test of Sphericity & Approx. Chi-Square & 37.610 \\
& df & 15 \\
& Sig. & .001 \\
\hline
\end{tabular}

Tabel 7. Hasil Anti-image Matrices Correlation Analisis Faktor Fisik Dominan

Penetu Prestasi Petanque

\begin{tabular}{lcccccc}
\hline \multicolumn{1}{c}{ Anti-image Correlatio } & $\begin{array}{c}\text { Tinggi } \\
\text { Badan }\end{array}$ & $\begin{array}{c}\text { Panjang } \\
\text { Lengan }\end{array}$ & $\begin{array}{c}\text { Kekuatan } \\
\text { Otot Lengan }\end{array}$ & $\begin{array}{c}\text { Kelentukan } \\
\text { Pergelangan } \\
\text { Tangan }\end{array}$ & Keseimbangan & $\begin{array}{c}\text { Koordinasi } \\
\text { Mata Tangan }\end{array}$ \\
\hline Tinggi Badan & $.609^{\mathrm{a}}$ & -.760 & .403 & -.058 & -.206 & -.165 \\
Panjang Lengan & -.760 & $.640^{\mathrm{a}}$ & -.060 & .227 & .260 & -.246 \\
Kekuatan Otot Lengan & .403 & -.060 & $.698^{\mathrm{a}}$ & .133 & -.370 & -.193 \\
Kelentukan Pergel. Tangan & -.058 & .227 & .133 & $.686^{\mathrm{a}}$ & -.498 & -.120 \\
Keseimbangan & -.206 & .260 & -.370 & -.498 & $.612^{\mathrm{a}}$ & -.316 \\
Koordinasi Mata Tangan & -.165 & -.246 & -.193 & -.120 & -.316 & $.688^{\mathrm{a}}$ \\
\hline
\end{tabular}

Tabel 8. Hasil Communalities

\begin{tabular}{lcc}
\hline & Initial & Extraction \\
\hline Tinggi Badan & 1.000 & .893 \\
Panjang Lengan & 1.000 & .881 \\
Kekuatan Otot Lengan & 1.000 & .569 \\
Kelentukan Pergelangan Tangan & 1.000 & .645 \\
Keseimbangan & 1.000 & .827 \\
Koordinasi Mata Tangan & 1.000 & .770 \\
\hline
\end{tabular}

Extraction Method: Principal Component Analysis. 
Jurnal Keolahragaan 7 (2), 2019 -121

Yulingga Nanda Hanief, Ardhi Mardiyanto Indra Purnomo

Tabel 9. Hasil Rotated Component Matrix ${ }^{a}$

\begin{tabular}{lrr}
\hline & \multirow{2}{*}{ Variabel } & \multicolumn{2}{c}{ Component } \\
\cline { 2 - 4 } & \multicolumn{3}{c}{} & \multicolumn{2}{c}{} \\
\hline Tinggi Badan & .937 & -.123 \\
Panjang Lengan & .898 & -.274 \\
Kekuatan Otot Lengan & -.505 & .560 \\
Kelentukan Pergelangan Tangan & -.145 & .790 \\
Keseimbangan & -.090 & .905 \\
Koordinasi Mata Tangan & .654 & .585 \\
\hline
\end{tabular}

\section{Factor Analysis II}

Hasil output KMO and Bartlett's Test (Tabel 6) menunjukkan nilai KMO-MSA sebesar 0,646 dan nilai Sig. $=0.001<0.05$, hal ini menunjukan bahwa kumpulan variabel pada penelitian ini adalah signifikan dan dapat diproses lebih lanjut.

Pada tabulasi Anti Image matrices (Tabel 7) ternyata tidak ada variabel yang memiliki nilai MSA di bawah 0,50 yang berarti semua variabel tersebut bisa diuji lebih lanjut menggunakan proses ekstraksi dengan metode Principal Component Analysis yang menghasilkan nilai Communalities.

Dari (Tabel 8) diketahui bahwa peranan dimensi yang terbesar adalah sub-variabel tinggi badan, dengan nilai sebesar 0,893 atau $89,3 \%$ dan yang terkecil adalah kekuatan otot lengan dengan nilai sebesar 0,569 atau 56,9\%. Kemudian untuk mengetahui sumbangan setiap variabel pada masing-masing komponen, perlu dilakukan proses rotasi yang menghasilkan component Matrix.

Hasil Rotated Component Matrix ${ }^{a}$ (Tabel 9) analisis faktor fisik dominan penetu prestasi petanque, ternyata semua komponen faktor mempunyai nilai $\geq 0,5$. Hal ini berarti bahwa dimensi faktor anthropometri dan biomotor tersebut yang terdiri dari variabel tinggi badan, panjang lengan, kekuatan otot lengan, kelentukan pergelangan tangan, keseimbangan, dan koordinasi mata-tangan merupakan anggota faktor variabel anthropometri dan biomotor penentu prestasi petanque.

\section{Pengujian Hipotesis}

Uji hipotesis dilakukan untuk menemukan kebenaran. Pengujian hipotesis pada penelitian ini dilakukan dengan melihat besarnya nilai hasil penghitungan Anti-image Matrices Correlation dan rotated component matrix ${ }^{a}$. Hasil uji hipotesis dari penelitian ini adalah:

Faktor Anthropometri Tinggi Badan dan Panjang Lengan

Tinggi Badan Menentukan Prestasi Petanque
Nilai faktor tinggi badan pada anti-image matrices correlation (Tabel 7) sebesar 0,609 atau $>0,5$ dengan nilai communalities (Tabel 8) sebesar 0,893 yang artinya tinggi badan mempunyai presentase peranan terhadap faktor sebesar 89,3\% dan nilai rotated component matrix sebesar 0,937 yang artinya tinggi badan merupakan anggota faktor anthropometri penentu prestasi petanque.

\section{Panjang Lengan Menentukan Prestasi Petanque}

Nilai faktor panjang lengan anti-image matrices correlation (Tabel 7) sebesar 0,640 atau $>0,5$ dengan nilai communalities (Tabel 8) sebesar 0,881 yang artinya panjang lengan mempunyai presentase peranan terhadap faktor sebesar $88,1 \%$ dan nilai rotated component matrix sebesar 0,898 yang artinya panjang lengan merupakan anggota faktor anthropometri penentu prestasi petanque.

Faktor Biomotor Kekuatan Otot Lengan, Kelentukan Pergelangan Tangan, Keseimbangan dan Koordinasi Mata-Tangan

\section{Kekuatan Otot Lengan Menentukan Prestasi Petanque}

Nilai faktor kekuatan otot lengan antiimage matrices correlation yang (Tabel 7) sebesar 0,698 atau > 0,5 dengan nilai communalities (Tabel 8) sebesar 0,569 yang artinya kekuatan otot lengan mempunyai presentase peranan terhadap faktor sebesar $56,9 \%$ dan nilai rotated component matrix sebesar 0,560 yang artinya kekuatan otot lengan merupakan anggota faktor biomotor penentu prestasi petanque.

\section{Kelentukan Pergelangan Tangan Menentukan Prestasi Petanque}

Nilai faktor kelentukan pergelangan tangan anti-image matrices correlation (Tabel 7) sebesar 0,686 atau >0,5 dengan nilai communalities (Tabel 8) sebesar 0,645 yang artinya kelentukan pergelangan tangan mempunyai presentase peranan terhadap faktor sebesar $64,5 \%$ dan nilai rotated component matrix sebesar 0,790 yang 
artinya kelentukan pergelangan tangan merupakan anggota faktor biomotor penentu prestasi petanque.

\section{Keseimbangan Menentukan Prestasi Petanque}

Nilai faktor keseimbangan anti-image matrices correlation (Tabel 7) sebesar 0,612 atau $>0,5$ dengan nilai communalities (Tabel 8) sebesar 0,827 yang artinya keseimbangan mempunyai presentase peranan terhadap faktor sebesar $82,7 \%$ dan nilai rotated component matrix sebesar 0,905 yang artinya keseimbangan merupakan anggota faktor biomotor penentu prestasi petanque.

\section{Koordinasi Mata-Tangan Menentukan Prestasi Petanque}

Nilai faktor koordinasi mata-tangan antiimage matrices correlation (Tabel 7) sebesar 0,688 atau $>0,5$ dengan nilai communalities (Tabel 8) sebesar 0,770 yang artinya koordinasi mata-tangan mempunyai presentase peranan terhadap faktor sebesar $77 \%$ dan nilai rotated component matrix sebesar 0,654 yang artinya koordinasi mata-tangan merupakan anggota faktor biomotor penentu prestasi petanque.

Berdasarkan hasil analisis data, ditemukan bahwa terdapat 1 (satu) variabel anthropometri dan 2 (dua) variabel biomotor yang dikeluarkan (eliminasi) dari faktor analisis dominan, karena nilai MSA dibawah 0,5 yakni panjang telapak tangan $(0,33)$, power otot lengan $(0,29)$, dan kekuatan peras tangan $(0,41)$. Temuan penelitian ini menunjukkan bahwa faktor anthropometri dan bimotor menentukan prestasi petanque, khususnya tinggi badan, panjang lengan, kekuatan otot lengan, kelentukan pergelangan tangan, keseimbangan, dan koordinasi mata-tangan. (Pyne, Duthie, Saunders, Petersen, \& Portus, 2006) menyoroti ukuran antropometrik dari daya tubuh bagian atas, panjang lengan, dan lompatan statis sebagai korelasi yang baik dari kecepatan bola puncak pada bowler junior dan cepat.

Pointing dan shooting merupakan teknik lemparan pada petanque, sehingga teknik tersebut menuntut akurasi ketepatan yang tinggi. Tuntutan fisiologis mengharuskan pemain untuk kompeten dalam beberapa aspek kebugaran, yang meliputi kekuatan aerobik dan anaerob, kekuatan otot, keseimbangan, fleksibilitas dan komposisi tubuh (distribusi serat otot, area penampang otot, massa volume kaki, dan lain-lain) (Turkmen, Ozkan, Bozkus, \& Kul, 2018). Selain faktor anthropometri dan biomotor, faktor biomekanika juga mempengaruhi hasil lemparan karena gerak manusia dipengaruhi oleh faktor biomekanik di mana untuk mengetahui sudut dan torsi tubuh yang ideal (Irawan et al., 2019). Jumlah sudut dan torsi saat melempar dan menembak juga harus mendapat perhatian yang lebih intensif, karena berkaitan erat dengan peningkatan kinerja dan pencegahan dari cedera (Irawan \& Long-Ren, 2015a, 2015b).

Sebagian orang berpikir bahwa bermain petanque terlihat mudah, namun secara teknik permainan ini hampir sama dengan golf (Lagueny et al., 2002), yaitu sama-sama melempar bola pada sasaran. Perbedaanya, dalam melempar bola, golf menggunakan stick, sementara petanque memanfaatkan tinggi badan dan panjang lengan untuk melakukan swing. Lengan yang panjang memainkan peran penting dalam jarak yang lebih jauh yang ditempuh, karena tuas yang lebih panjang selalu memiliki keuntungan dalam melempar (Singh \& Singh, 2015). Hasil lemparan bola dilaporkan berkorelasi positif dengan ukuran tubuh, panjang ekstremitas atas dan bawah (Zapartidis et al., 2009). Penelitian yang dilakukan oleh (van den Tillaar \& Ettema, 2004) menyimpulkan bahwa tinggi badan mempunyai korelasi positif pada hasil lemparan bola, sehingga penelitian tersebut memperkuat hasil temuan pada penelitian ini.

Keberhasilan dalam melempar bola besi tidak terlepas dari peran kekuatan otot lengan (Nicholson, Hulburt, Kimura, \& Aguinaldo, 2019). Lemparan yang baik menghasilkan lintasan parabola, sehingga memerlukan sudut lemparan dan kekuatan lemparan. Ayunan lengan dengan memegang bola besi adalah buah dari kekuatan otot lengan. Stabilisasi glenohumeral dan kekuatan otot adalah salah satu faktor terpenting untuk mengembangkan kecepatan lemparan bola (M. D. S. Andrade, Fleury, de Lira, Dubas, \& da Silva, 2010). Namun kelelahan otot juga dapat berdampak pada akurasi melempar (M. S. Andrade, de Carvalho Koffes, BeneditoSilva, da Silva, \& de Lira, 2016), karena pada permainan petanque memiliki banyak babak pertandingan sehingga tidak tertutup kemungkinan adanaya faktor kelelahan (fatique). Sejumlah penelitian telah menyelidiki kekuatan otot dan keseimbangan otot bahu dalam upaya untuk mengidentifikasi hubungan dengan hasil lempar (Bayios, Anastasopoulou, Sioudris, \& Boudolos, 2001).

Hasil studi oleh (Irawan et al., 2019) menunjukkan bahwa sebanyak 5 sampel dengan persentase $31,2 \%$ yang menjelaskan konsentrasi dan koordinasi mata-tangan menentukan hasil 
lemparan pada sudut backswing $80^{\circ}$. Konsentrasi dan koordinasi tangan-mata sangat penting untuk menjaga agar pemain tetap fokus pada target shooting. Mengurangi satu bagian baik konsentrasi atau koordinasi-mata-tangan akan mengurangi intensitas kemampuan dan hasil lemparan (shooting) tidak maksimal. Urgensi koordinasi mata-tangan pada petanque diperkuat oleh penelitian yang dilakukan oleh (Agustini, Nugraheni, \& Maulana, 2018; Manjayati, 2018; Mudhalifa, 2018; Widodo \& Hafidz, 2018) yang menyimpulkan koordinasi mata-tangan memberi sumbangan terhadap ketepatan shooting.

\section{SIMPULAN}

Hasil temuan pada penelitian ini dapat disimpulkan faktor fisik dominan penentu pretasi petanque adalah tinggi badan, panjang lengan, kekuatan otot lengan, kelentukan pergelangan tangan, keseimbangan, dan koordinasi matatangan. Penelitian ini hanya melibatkan atlet tingkat daerah, sehingga hasil penelitian ini belum dapat di generalisasi. Perlu penelitian lanjut yang melibatkan elit atlet dengan jumlah yang banyak sehingga dapat digeneralisasi.

\section{UCAPAN TERIMA KASIH}

Penelitian ini dibiayai oleh Direktorat Riset dan Pengabdian Masyarakat Direktorat Jenderal Penguatan Riset dan Pengembangan Kementrian Riset, Teknologi, dan Pendidikan Tinggi Sesuai dengan kontrak penelitian Nomor: 056/SP2H/LT/MONO/L7/2019, tanggal 26 Maret 2019 dengan skim Penelitian Dosen Pemula (PDP). Terima kasih kami sampaikan sehingga penelitian ini berhasil terlaksana dan semoga temuan pada penelitian ini dapat bermanfaat.

\section{DAFTAR PUSTAKA}

Agustina, A. T., \& Priambodo, A. (2017). Hubungan antara tingkat konsentrasi terhadap hasil ketepatan shooting olahraga petanque pada peserta Unesa Petanque Club. Jurnal Pendidikan Olahraga Dan Kesehatan, 5(3). Retrieved from https://jurnalmahasiswa.unesa.ac.id/index. php/jurnal-pendidikanjasmani/article/view/19598

Agustini, D. K., Nugraheni, W., \& Maulana, F. (2018). Hubungan kekuatan otot lengan dan koordinasi mata tangan terhadap ketepatan shooting dalam olahraga pétanque di klub Kota Sukabumi tahun 2018. Universitas Muhammadiyah
Sukabumi. $\quad$ Retrieved from http://eprints.ummi.ac.id/453/

Andrade, M. D. S., Fleury, A. M., de Lira, C. A. B., Dubas, J. P., \& da Silva, A. C. (2010). Profile of isokinetic eccentric-toconcentric strength ratios of shoulder rotator muscles in elite female team handball players. Journal of Sports Sciences, 28(7), 743-749. https://doi.org/10.1080/026404110036456 87

Andrade, M. S., de Carvalho Koffes, F., Benedito-Silva, A. A., da Silva, A. C., \& de Lira, C. A. B. (2016). Effect of fatigue caused by a simulated handball game on ball throwing velocity, shoulder muscle strength and balance ratio: a prospective study. BMC Sports Science, Medicine and Rehabilitation, $8(1), \quad 13$. https://doi.org/10.1186/s13102-016-00389

Bayios, I. A., Anastasopoulou, E. M., Sioudris, D. S., \& Boudolos, K. D. (2001). Relationship between isokinetic strength of the internal and external shoulder rotators and ball velocity in team handball. Journal of Sports Medicine and Physical Fitness, 41(2), 229-235. Retrieved from https://www.minervamedica.it/en/journals /sports-med-physical-

fitness/article.php?cod=R40Y2001N02A0 229

Hanief, Y. N., \& Himawanto, W. (2017). Statistik pendidikan. Yogyakarta: Deepublish.

Hernández, J. G., \& de los Fayos, E. J. G. (2009). Plan de entrenamiento psicológico en el deporte de la petanca: en búsqueda del rendimiento grupal óptimo. Revista de Psicología Del Deporte, 18(1), 87-104. Retrieved from https://www.rpdonline.com/article/view/6

Irawan, F. A., \& Long-Ren, C. (2015a). Comprehensive pitching biomechanics and injury prevention for young baseball pitchers-a review. Journal of Physical Education and Sport Science, 21, 11-21.

Irawan, F. A., \& Long-Ren, C. (2015b). Pitching biomechanics and injury prevention to improving performance for young baseball pitchers - A review. In 1st UNNES International Conference on Research Innovation \& COmmercialization for Better Life. Semarang: Universitas Negeri 
Semarang.

Irawan, F. A., Permana, D. F. W., Akromawati, H. R., \& Yang-Tian, H. (2019). Biomechanical analysis of concentration and coordination on the accuracy in petanque shooting. ACTIVE: Journal of Physical Education, Sport, Health and Recreation, 8(2), 96-100. https://doi.org/10.15294/active.v8i2.3046 7

Isknadar, T., Ridlo, A. F., \& Oktaviana, Y. D. (2019). The effect of dumbbell swing exercise method to the arms muscle strength of petanque athletes. In 2nd International Conference on Sports Sciences and Health 2018 (2nd ICSSH 2018). Atlantis Press. Retrieved from https://www.atlantis-

press.com/proceedings/icssh-

$18 / 55914054$

Juhanis, J., B, B., \& Nur, M. (2019). Pelatihan teknik dasar dan sosialisasi peraturan permaian olahraga Petanque pada mahasiswa FIK UNM Makassar. In Seminar Nasional Pengabdian Kepada Masyarakat (Vol. 2018). Retrieved from https://ojs.unm.ac.id/semnaslpm/article/vi ew/7816

Lagueny, A., Burbaud, P., Dubos, J. L., le Masson, G., Guelh, D., Macia, F., ... Tison, F. (2002). Freezing of shoulder flexion impeding boule throwing: A form of task-specific focal dystonia in petanque players. Movement Disorders, 17(5), 1092-1095.

https://doi.org/10.1002/mds.10228

Laksana, G. B., Pramono, H., \& Mukarromah, S. B. (2017). Perspektif olahraga petanque dalam mendukung prestasi olahraga jawa tengah. Journal of Physical Education and Sports, 6(1), 36-43. Retrieved from https://journal.unnes.ac.id/sju/index.php/j pes/article/view/17319

Loser, R., Piskoty, G., Al-Badri, A., Tuchschmid, M., Schmid, P., \& Leemann, A. (2011). Investigation into the mechanisms leading to explosion of pétanque balls. Engineering Failure Analysis, 18(2), 633648.

https://doi.org/10.1016/j.engfailanal.2010. 09.029

Manjayati, E. S. A. (2018). Hubungan antara tinggi badan, keseimbangan, kelentukan otot punggung,koordinasi mata dan tangan, dwngan hasil ketepatan shooting olahraga petanque pada atlet klub petanque Kediri tahun 2017/2018. Jurnal SimkiTechsain, 2(2). Retrieved from http://simki.unpkediri.ac.id/detail/14.1.01. 09.0055

Mudhalifa, M. (2018). Hubungan kekuatan otot lengan, koordinasi mata tangan dan keseimbangan terhadap hasil ketepatan shooting petanque pada atlet klub petanque Kediri 2017/2018. Jurnal Simki-Techsain, 2(4). Retrieved from http://simki.unpkediri.ac.id/detail/13.1.01. 09.0108

Muladana, A. (2019). Perbedaan latihan shooting menggunakan penghalang dan tanpa penghalang terhadap peningkatan kemampuan shooting game atlet pemula petanque. Ikora, 8(2). Retrieved from http://journal.student.uny.ac.id/ojs/ojs/ind ex.php/ikora/article/view/15092

Nicholson, K. F., Hulburt, T. C., Kimura, B. M., \& Aguinaldo, A. (2019). Relationship between ground reaction force and throwing arm kinetics in high school and collegiate baseball pitchers. ISBS Proceedings Archive, 37(1), 316. Retrieved from https://commons.nmu.edu/isbs/vol37/iss1/ 77/

Okilanda, A., Arisman, A., Lestari, H., Lanos, M. E. C., Fajar, M., Putri, S. A. R., \& Sugarwanto, S. (2018). Sosialisasi petanque sebagai olahraga masa kini. Bagimu Negeri: Jurnal Pengabdian Masyarakat, 2(1). https://doi.org/10.26638/jbn.638.8651

Pradana, S. W. K. C., \& Nurkholis, N. (2019). Kontribusi tinggi badan, panjang lengan, keseimbangan, konsentrasi dan persepsi kinestetik terhadap ketepatan shooting pada olahraga petanque. Jurnal Prestasi Olahraga, 1(1). Retrieved from https://jurnalmahasiswa.unesa.ac.id/index. php/jurnal-prestasiolahraga/article/view/26919

Pyne, D. B., Duthie, G. M., Saunders, P. U., Petersen, C. A., \& Portus, M. R. (2006). Anthropometric and strength correlates of fast bowling speed in junior and senior cricketers. Journal of Strength and Conditioning Research, 20(3), 620. 
Jurnal Keolahragaan 7 (2), 2019 -125

Yulingga Nanda Hanief, Ardhi Mardiyanto Indra Purnomo

Retrieved

from

http://vuir.vu.edu.au/id/eprint/31989

Rizal, A. (2012). Kontribusi panjang lengan, kelentukan pergelangan tangan terhadap kemampuanpukulan dropshot bulutangkis mahasiswa FIK UNM Makassar. Jurnal Penelitian Pendidikan " Pendidikan Jasmani Kesehatan Dan Rekreasi," 3(3), $1-153$.

Sinaga, F. S. G. (2019). Analysis biomechanics pointing dan shooting petanque pada atlet TC PON XX PAPUA. Sains Olahraga: Jurnal Ilmiah Ilmu Keolahragaan, 3(2), $66-75$.

Singh, K., \& Singh, R. (2015). Relationship of selected anthropometric variables with the throwing distance of cricket ball in cricket. Academic Sports Scholars, 4(8), 1-6.

Souef, G. (2015). The winning trajectory. Copy Media.

Sudiadharma, S., \& Suardi, S. (2019). Pelatihan teknik dasar dan pembuatan lapangan olahraga permainan petanque pada remaja Mesjid Nurul Huda di Kabupaten Takalar. In Seminar Nasional Pengabdian Kepada Masyarakat (Vol. 2019). Retrieved from https://ojs.unm.ac.id/semnaslpm/article/vi ew/11074

Suwanto, W., Kristiyanto, A., \& Doewes, M. (2018). Development of petanque sport in Central Java Province. Journal of Education, Health and Sport, 8(11), 194198.

https://doi.org/10.5281/zenodo.1479007
Turkmen, M., Bozkus, T., \& Altintas, A. (2013). The relationship between motivation orientations and competitive anxiety in Bocce players: Does gender make a difference. Psychology and Behavioral Sciences, 2(4), 162-168.

Turkmen, M., Ozkan, A., Bozkus, T., \& Kul, M. (2018). Determination of some physical fitness and body composition characteristics of young bocce players in Turkish national team. Sport Mont, 16(1), 3-7. https://doi.org/10.26773/smj.180201

van den Tillaar, R., \& Ettema, G. (2004). Effect of body size and gender in overarm throwing performance. European Journal of Applied Physiology, 91(4), 413-418. https://doi.org/10.1007/s00421-003-10198

Widodo, W., \& Hafidz, A. (2018). Kontribusi panjang lengan, koordinasi mata tangan, dan konsentrasi terhadap ketepatan shooting pada olahraga petanque. Jurnal Prestasi Olahraga, 3(1). Retrieved from https://jurnalmahasiswa.unesa.ac.id/index. php/jurnal-prestasi-

olahraga/article/view/24070

Zapartidis, I., Skoufas, D., Vareltzis, I., Christodoulidis, T., Toganidis, T., \& Kororos, P. (2009). Factors influencing ball throwing velocity in young female handball players. The Open Sports Medicine Journal, 3(1), 39-43. https://doi.org/10.2174/187438700090301 0039 